\title{
Obituary
}

\section{Remembering Sheila Whiteley}

It was with great sadness that we learnt of the death of our esteemed colleague in June this year. Both Derek Scott and Stan Hawkins worked with her in various capacities for many years, and we asked them to convey something of Sheila's accomplishments and spirit for our readers.

\section{Tribute given by Derek B. Scott at the Funeral of Sheila Whiteley (Hove, UK, 24 June 2015)}

This is a sad and trying occasion for us all. I am here to pay tribute to Sheila, but she was not someone any of us can talk about merely in terms of admiration and respect - she was a person we loved. What I would like to do is to give an idea of the impact Sheila's life had on others. In speaking of such a full and active life, I have no option but to be selective.

First, I must mention her work as a teacher at the University of Salford. She was one of a group of lecturers who set up the UK's very first degree in popular music in the early 1990s. At the time, many saw it as an outrageous development, but Sheila was never afraid of outrage. This degree set the standards for the academic study of popular music at undergraduate level and was soon being imitated elsewhere in higher education. Sheila was, herself, an inspirational teacher, as any student who attended her lectures on style and genre will confirm. At postgraduate level, she showed exceptional generosity in the time she devoted to supervision and mentoring.

Sheila was not only a dedicated teacher, but she also had a social conscience and a keen sense of social commitment. She played a key part in setting up and ensuring the success of Freeflow, a project designed to showcase the talents of young musicians. She worked on two major projects funded by the European Social Fund, examining conditions and job opportunities for women working, or seeking to work, in the creative industries. She reached out to involve industry bosses and leading politicians, and brought each project to a successful conclusion.

Sheila published prolifically as an academic, so I am forced to be even more selective in my comments on this aspect of her career. Her first book, The Space Between the Notes (1992), was the first attempt to provide an analysis of the representation of drug-induced hallucinogenic experience in the rock music of the counterculture. The originality of the book is that, unlike much sociological work on this topic, it focused on the music and on what particular musical devices signified in the context of psychedelia. For her next book, Sexing the Groove (1997), she put together a collection of essays in which she and other scholars demonstrated the links between music and sexuality. This was a topic that she continued to investigate throughout her academic career. 
Another work I will single out is her book on child stars, Too Much, Too Young (2005), which led her into so many copyright problems that she became a leading campaigner for the 'fair use' of quotation in criticism and review. There was always a provision in law for this, but many publishers were worried about being prosecuted by wealthy rights owners. Sheila was instrumental in persuading publishers that they should use the opportunity allowed by law. If they did not, it would mean that scholars could not publish critical work on any music that was in copyright.

I will mention just two more publications. One is her essay on Jimi Hendrix's performance of 'The Star-Spangled Banner' at Woodstock. In a detailed comparison of the lyrics of the anthem and the techniques used by Hendrix she once again enlightens us concerning the workings of representative devices in music. This essay is, to my mind, the single most informative account of Hendrix's legendary performance. And so, lastly, I turn to Women in Popular Music (2002), which enjoys what might be called 'classic status' among Sheila's books. It appears on just about every college and university reading list for courses that deal with music and gender issues. This book alone will ensure that Sheila is remembered in the world of academia.

There are, however, unwritten memories I have of Sheila that will never die. So, let me end with some recollections of Sheila at academic conferences. Like Sheila, I am someone who doesn't fully waken until later in the morning. For this reason, it was always pleasant when we met at breakfast, because neither of us felt any need to make an effort to be sociable. Unfortunately, at a conference in London, an enthusiastic delegate joined us at our table and began speaking excitedly about the day's forthcoming events. Sheila cast a bleary eye in his direction and said, 'I don't mean to be rude, but Derek and I don't speak at breakfast'.

I remember Sheila causing me pain on two separate occasions at a conference in Jyväskylä, Finland. First, she hit me hard on the neck, claiming to have killed a mosquito. I was unable to thank her - in fact, I was unable to talk at all for some time. The second incident involved an intoxicated philanderer in a bar. Sheila was a beautiful woman, whose charms frequently attracted the attentions of the 'wrong kind of man'. The first I knew of it on this occasion was when I felt a kick to my shin. I chose not to make a fuss. Then I felt an even sharper kick, and looking at Sheila I saw that she was trying to remove a man's arm from her shoulder. At this point, I responded with some rather overdue chivalry and extricated her from his grasp.

Finally, I will never forget Sheila's paper on vinyl albums, given at a conference in Birmingham. She played a Dusty Springfield song from an LP she had bought at a Manchester market. Some of the younger delegates had never heard such loud and intrusive vinyl crackle, and they must have been wondering why she didn't play a digital recording instead. Sheila then went on to explain that only a vinyl album provided evidence of the songs someone really loved. She had found a novel way of establishing which songs meant most to young women in the 1960s and 1970s by examining the worn-out tracks in the albums they owned. It was this kind of originality that made Sheila Whiteley into that rare mixture of warm, sensitive human being and insightful academic. Like those of you who have gathered here today, and many who could not attend this service, I will never stop missing her.

Postscript: I presented this tribute with the aid of very brief notes. I knew that it would be easier to control my emotion if I forced myself to think about what I was going to say, and not simply to read a pre-prepared text. One thing I regret not 
saying was that most scholars of popular music (myself included) find that they begin to have less of a grasp on more recent popular developments as they get older. That was never the case with Sheila. Her body may have aged, but in her mind she never became old.

\section{Stan Hawkins remembering Sheila Whiteley}

It was during the very early years of my academic career at Salford University in the early 1990s that I first met Sheila Whiteley. We were looking for a scholar to join our team while developing popular music and recording degrees. The appointee was required to complement the existing strands in composition, recording and performance studies and to beef up the academic aspects of our course. I well recall Sheila's application for this post. The originality of her work shone through, with every sign that she would be an ideal member of our team when we recruited her in 1991. Her subsequent appointment was a coup for all of us. Already her seminal article on Jimi Hendrix had appeared in this same journal. Path-breaking for its time from a musicological perspective, it addressed the role of hallucinogenic drugs, sex and progressive rock through new music analytic methods. The Space Between the Notes, Sheila's first monograph, was published during her initial year at Salford, and I remember her gleefully showing it to me. Not only did this book prove to inspire a generation of younger researchers such as myself, but also music students, who in those days were eager for new literature.

My own transition from teaching composition and starting the Popular Music Research Unit at Salford, to musicology, and my subsequent recruitment to Oslo University's Musicology Department, owes a great deal to Sheila's influence, support and inspiration. Mostly, it was her pioneering approach to gender studies within popular musicology that egged me on to take a more interdisciplinary approach to music analysis, where matters of identity, agency and subjectivity would assume centre stage in all my research. I was fortunate enough to be a part of a number of joint projects instigated by her, such as Sexing the Groove, Music, Space, and Place and Queering the Popular Pitch. Sheila's sheer dedication to popular music studies was awe inspiring. She was devoted to the association, IASPM, for which she was general secretary (1999-2001) and this involved our attending memorable conferences together. With fond memories I recall being with her at Stockton (1993), Sydney (1999) and Turku (2001), and the great fun we had together. Sheila had an infectious giggle that often turned into a hoot, at times getting us into trouble.

Over the years, Sheila would present her latest research and participate in various seminars in my department in Oslo, where popular music research had gradually taken off. She always had the knack for captivating the interest of our students through her sharp intellect, wit and charisma. Communicating tricky concepts in an engaged, uncomplicated and sensitive manner, she was fiercely passionate about social politics and equal opportunities. Sheila was the kind of feminist scholar who never intimidated, but rather reasoned in a down-to-earth fashion. That so many more male music students are involved in gender research today is due to the approach Sheila adopted, and the unpatronising manner with which she conveyed her ideas. It needs to be said that she loved all genres of music and had no prejudices whatsoever along the lines of style. She had an admiration and respect for musical creativity, no matter who the artist or band was, grasping the 
fundaments of music aesthetics. In retrospect, her role in importing gender studies into popular musicology was a remarkable achievement. Her approach to this was often rebellious. After all, she was an intellectual provocateur. I often felt that she had the same fervour as the two male rock stars she loved most - her outlandish contemporaries, Jimi Hendrix and Mick Jagger. It would be fair to say that because of her total commitment to music research and her studies of the artists we all adore, our field burgeons today in the wake of her remarkable publications.

Blessed with a vibrant personality and a burning enthusiasm for music research, Sheila was a natural-born teacher and adored by her students. A pioneer within the field of popular music studies, she produced work that will continue to motivate future generations of popular music students. Most of all, she was a loyal and trustworthy friend, whose support will live on in all of us who were fortunate enough to be close to her. 